\title{
Commentary: Empathy and its discontents
}

\author{
Daniel Västfjäll ${ }^{1,2 *}$, Arvid Erlandsson ${ }^{1,3}$, Paul Slovic $^{2,4}$ and Gustav Tinghög ${ }^{1}$ \\ 1 Judgment, Emotion, Decision, Intuition Lab, Linköping University, Linköping, Sweden, ${ }^{2}$ Decision Research, Eugene, OR, \\ USA, ${ }^{3}$ Department of Psychology, Lund University, Lund, Sweden, ${ }^{4}$ Department of Psychology, University of Oregon, \\ Eugene, OR, USA
}

Keywords: empathy, compassion, decision making, psychic numbing, public policy

\section{A commentary on}

Empathy and its discontents

by Bloom, P. (2017). Trends Cogn. Sci. 21, 24-31. doi: 10.1016/j.tics.2016.11.004

\section{WE SHOULD BE EQUALLY DISCONTENT WITH EMPATHY AND COMPASSION}

In "Empathy and its discontents" Bloom (2017: see also Bloom, 2016) argues that we should abandon empathy as a moral compass in favor of compassion. Bloom's central premise is that empathy is narrow in its focus on single identified individuals, biased in that it favors the in-group, and can be used as a tool to motivate us to do things that are not optimally effective, or even destructive (e.g., motivate war). For all these reasons, Bloom argues that policy decision should not be motivated by empathy. There is indeed ample evidence that empathy is fraught with biases and we have, as Bloom, argued that deliberate mechanisms are needed to counteract the innumeracy and parochialism of empathy (Slovic and Västfjäll, 2010). While there is much to agree with Bloom on, there are a few points where we disagree; (1) the definition of compassion, (2) data supporting why empathy, but not compassion, is bad, (3) the role of deliberation in moral judgment.

\section{WELL-DEFINED “EMPATHY” BUT ILL-DEFINED “COMPASSION”}

Bloom is against empathy but for compassion. Whereas, empathy in Bloom's definition is clearly explained and consistent in different papers ("experiencing what you think others are experiencing"), the same cannot be said for compassion. In the Trend in Cognitive Sciences article [1] it is "positive feelings toward others, a desire that others do well and do not suffer...", but elsewhere it is defined by Bloom similarly as to what Batson (2011) refers to as empathic concern (e.g., "I am often touched by things that I see happen"; (Jordan et al., 2016), or as "a more distanced love and kindness and concern for others" (Bloom, 2014). Adding to the confusion, other compassion scholars define it as "feeling sorrow or concern for the suffering of another person, coupled with the desire to alleviate that suffering" (Keltner, 2014). This conceptual vagueness makes it difficult to tell how compassion may be "better prod to moral action" (Bloom, 2017, p. 24) and to make such a claim we need to carefully distinguish how compassion is different from empathy.

\section{DATA SUPPORTING WHY EMPATHY IS BAD}

It could be argued that no matter which definition of compassion one prefer, relying on it as a moral motive will lead to just as serious biases as relying on empathy. In fact, much of the literature Bloom 
cites to support his argument does not assess empathy (as he defines it) but is more in line with his definition of compassion. For instance, the work cited by Bloom on the identifiable victim effect (giving more to a victim with a name and a face compared to a statistical victim; Slovic, 2007) as well as the singularity effect (giving more to the one than to the many) has not been found to be driven by empathy but rather a drop in compassion (as measured both by self-report and physiology; Västfjäll et al., 2014). Compassion scholars acknowledge the biased nature of compassion: "...individuals who encounter the suffering of large numbers of people (e.g. starvation in Sudan) are more likely to respond with sadness, distress or even apathy as a result of their inability to cope with suffering of such a large magnitude" (Keltner, 2014, p. 331). In support of his distinction between empathy and compassion, Bloom cites work by Singer and Klimecki (2014) on the difference between mindul cold compassion and empathic affect sharing. Although we recognize that compassion training could lead to different brain activity and a smaller risk of apathy than empathy training in some cases, this does not imply that compassion is not fraught with many of the same biases as empathy. Given this it is difficult for us to see how compassion could be a better moral compass than empathy. We think of them as equally poor without the guidance of deliberative analysis.

\section{THE ROLE OF REASON}

One reading of Bloom is that he is not against empathy per se, but rather, against emotions in general (including empathy but also compassion, kindness, and love) as the motivator of moral decisions (see also commentary by Zaki, 2017). Bloom argues that utilitarian cost-benefit analyses and moral principles would be better guides for moral behavior. We agree that these are good alternatives for deciding what to do and what to avoid. However, it would not be fair to blame all biases on emotions. Previous work shows that biased cost-benefit analyses underlie the proportion dominance effect (saving 20 out of 25 rather than 22 out of 300 ), and perceived responsibility underlies the ingroup effect (helping few fellow countrymen rather than many from another country; Fetherstonhaugh et al., 1997; Erlandsson et al., 2015). Further, there is evidence that moral decisions made under intuitive

\section{REFERENCES}

Batson, C. D. (2011). Altruism in Humans. New York, NY: Oxford University Press. Bloom, P. (2014). Against Empathy. Boston Review. Available online at: http:// bostonreview.net/forum/paul-bloom-against-empathy

Bloom, P. (2016). Against Empathy: The Case of Rational Compassion. New York, NY: Ecco Press.

Bloom, P. (2017). Empathy and its discontents. Trends Cogn. Sci. 21, 24-31. doi: 10.1016/j.tics.2016.11.004

Erlandsson, A., Björklund, F., and Bäckström, M. (2015). Emotional reactions, perceived impact and perceived responsibility mediate the identifiable victim effect, proportion dominance effect and in-group effect respectively. Organ. Behav. Hum. Decis. Process. 127, 1-14. doi: 10.1016/j.obhdp.2014. 11.003 modes of thinking are no different from those that are made deliberatively Tinghög et al., 2016). Although we believe that both empathy and compassion are poor guides when assessing what is right and wrong, emotional reactions can be useful tools for motivating people to act morally. For example, highly emotional information in the form of personal stories or dramatic images (such as the picture of Alan Kurdi-the dead Syrian boy on a beach in Turkey) is often the spark that motivates people to act (Slovic et al., 2017). In these situations, intense emotions can motivate people to e.g. start making monthly donations, which likely will continue long after the emotional reactions have disappeared, thus benefitting also statistical victims. Another related point is brought up by Zaki (2017) affect and deliberation are intertwined and completely separating reason from feelings in moral decisions is likely an impossible task.

In sum, we agree with Bloom that people rely too singlemindedly on emotions (both empathy and compassion) when making moral decisions. However, some form of emotion (regardless of how biased it is) may be a necessary, though not sufficient, condition for action by both individuals and societies. Zaki (2017) points to the fact that emotion are not inherently good or bad-rather it is the context that determine their functional value. We agree that this is especially true for the affective component of compassion and empathy-sometimes emotion is needed to energize action, sometimes emotion will lead to biased decisions. What we need are deliberatively designed policies, laws, and institutions that can capitalize on our emotional responses and transform their motivational push to align with our moral values consistently across contexts (Slovic, 2007; Slovic et al., 2017).

\section{AUTHOR CONTRIBUTIONS}

All authors listed, have made substantial, direct and intellectual contribution to the work, and approved it for publication.

\section{FUNDING}

This research was funded by grants from National Science Foundation, Vetenskapsrådet, and Riksbankens Jubileumsfond.
Fetherstonhaugh, D., Slovic, P., Johnson, S. M., and Friedrich, J. (1997). Insensitivity to the value of human life: a study of psychophysical numbing. J. Risk Uncertain. 14, 283-300.

Jordan, M. R., Amirm, D., and Bloom, P. (2016). Are empathy and concern psychologically distinct?. Emotion 16:1107. doi: 10.1037/emo0000228

Keltner, D. (2014). Compassion. H Pos Emo. New York, NY: Guilford.

Singer, T., and Klimecki, O. M. (2014). Empathy and compassion. Curr. Biol. 24, R875-R878. doi: 10.1016/j.cub.2014.06.054

Slovic, P. (2007). "If I look at the mass I will never act": psychic numbing and genocide. Judgm. Decis. Mak. 2, 79-95.

Slovic, P., and Västfjäll, D. (2010). Affect, moral intuition, and risk. Psychol. Inquiry 21, 387-398. doi: 10.1080/1047840X.2010.521119

Slovic, P., Västfjäll, D., Erlandsson, A., and Gregory, R. (2017). Iconic photographs and the ebb and flow of empathic response to humanitarian 
disasters. Proc. Natl. Acad. Sci. U.S.A. 114, 640-644. doi: 10.1073/pnas.16139 77114

Tinghög, G., Andersson, D., Bonn, C., Johannesson, M., Kirchler, M., Koppel, L., et al. (2016). Intuition and moral decision-making - the effect of time pressure and cognitive load on moral judgment and altruistic behavior. PLoS ONE 11:e0164012. doi: 10.1371/journal.pone.0164012

Västfjäll, D., Slovic, P., Mayorga, M., and Peters, E. (2014). Compassion fade: affect and charity are greatest for a single child in need. PLoS ONE 9:e100115. doi: 10.1371/journal.pone. 0100115

Zaki, J. (2017). Moving beyond sterotypes of empathy. Trends Cogn. Sci. 21, 59-60. doi: $10.1016 /$ j.tics.2016.12.004
Conflict of Interest Statement: The authors declare that the research was conducted in the absence of any commercial or financial relationships that could be construed as a potential conflict of interest.

Copyright () 2017 Västfjäll, Erlandsson, Slovic and Tinghög. This is an openaccess article distributed under the terms of the Creative Commons Attribution License (CC BY). The use, distribution or reproduction in other forums is permitted, provided the original author(s) or licensor are credited and that the original publication in this journal is cited, in accordance with accepted academic practice. No use, distribution or reproduction is permitted which does not comply with these terms. 